\title{
Innovation in stem cell advocacy: you only get what you can measure
}

\section{Alan L Jakimo* \& Alan C Fernandez}

We propose that stem cell advocacy must engage in self-analysis to determine how to be maximally effective. For this analysis, eight advocacy elements can be measured: agitation, legislation, regulation, litigation, policy development, collaboration, education and innovation. For several of these elements, we show that stem cell advocates, particularly advocates for human embryonic stem cell research, have been matched by their opponents. This demonstrates the need for combining innovation and collaboration with advocacy-oriented education. To pursue innovative and collaborative education, we propose a 'bench-topublic knowledge' model and present some preliminary observations made with this model for different stem cell types. We also propose development of a semantic web information system to be operated within Internet Cloud/Apps/Social Media. We call this system the 'Stem Cell Information Technology Accelerator Platform'. Toward its construction, we propose formation of a working group to conceive semantic web ontology for stem cell science and its clinical translation into medicine. This ontology would function as a map of the relationships between and among the various informational components comprising discourse on stem cell research and its clinical translation, and would allow various stakeholders to contribute to evolving models of that science and translation. These models could, in turn, support an innovative and collaborative approach to education in furtherance of stem cell advocacy.

\section{"...Martin Luther King said the tools for advocacy were agitation, legislation, litigation and education. I would add to that, innovation." \\ - Robert F Kennedy Jr [101,102]}

The 'you only get what you can measure' mantra applies broadly in medicine and healthcare, from manufacturing medical products to translating science into medicine. We explore here the hypothesis that this principle applies equally to stem cell advocacy, and we begin by defining the terms 'stem cell' and 'advocacy'.

To define 'stem cell', we incorporate the broad meaning of the term presented by the US NIH: "[c]ells with the ability to divide for indefinite periods in culture and to give rise to specialized cells" [103]. While this definition extends beyond stem cells derived from human embryos (human embryonic stem cells [hESCs]), the status of hESC research may influence the entire stem cell field. In early 2011, researcher Aaron Levine reported that "[a] survey of US stem cell scientists shows that uncertainty following the legal challenge to the Obama Administration's hESC research policy has negative scientific and economic impacts and affects a range of stem cell scientists, not just those working with hESCs" [1].

To define 'advocacy', we note that the Latin word 'vocare' ('to call') forms the root of 'advocare' ('to call as witness'). Etymologically, 'stem cell advocacy' thus refers to calling forth the benefits of acquiring knowledge of stem cells and converting that knowledge into medical and other potential technologies [2].

"Author for correspondence: Alan L Jakimo, Sidley Austin LLP, 787 Seventh Avenue, NY 10019, USA; ajakimo@sidley.com

Alan C Fernandez, Genetics Policy Institute, Palo Alto, CA, USA

Hippocrates's oath prohibits new fields of medicine from developing without canonical protection of patient safety [104]. Consequently, we cannot criticize the historic pace at which medicine has been translated from stem cell science. Instead, we seek to explore whether advocates for this science and its translation into medicine have been effective during the past 30-plus years. For this purpose we propose measuring each of the following elements of advocacy: agitation, legislation, regulation, litigation, policy development, collaboration, education and innovation.

Applied to stem cell research, the kinetic energy to which each of these eight forces gives rise must be measured in at least two directions: the first points in favor of such research; the second, in the opposite direction.

To illustrate this bivalence, consider a very serious disease (VSD). Generally, if VSD is chronic in nature or does not 
threaten pandemic infectious lethality, and patients suffering from VSD do relatively little to advocate developing cures for it, then there is at least some chance, all other things being equal, that a cure for VSD will eventually be found. However, if opponents of technology that may lead to that cure agitate against its use more so than proponents agitate for its use, then the chances of finding that cure will diminish.

But, when the VSD involves the threat of pandemic infectious lethality, a different result can be obtained. In the late 1980s, for example, communities at higher risk for being infected and dying from the sequelae of HIV infection brought their agitation to the US Capitol. Their agitation had traction given the uncertainty as to just how far the causative virus would spread. The urgency in this example, however, does not map into stem cellbased medicine, where, historically (except for a few notable exceptions at the state government level in the USA), there seems to have been more agitation among opponents of stem cell research, particularly hESC research, than among proponents of that research.

The reflection of this historic imbalance can be seen in two sets of opposing legislative and regulatory events.

The first set, in chronological order, comprises:

- The September 1980 'Catch 22' decision by the US Department of Health and Human Services making it impossible for the NIH to fund research of in vitro fertilization [3];

- A 13-year period (1980-1993) during which fetal tissue research in the USA was significantly curtailed due to federal funding policy opposed to such research;

- The December 1994 US Presidential directive to the NIH not to allocate federal funds for the 'creation' of human embryos for research purposes;
- The signing into law in 1996 of the first Dickey-Wicker Amendment, an annually re-enacted law that prohibits US government funding for creating human embryos for research purposes and research in which human embryos are destroyed, discarded or knowingly subjected to risks greater than that allowed for research on fetuses in utero under the Common Rule (the set of US federal rules for protecting human subjects in research);

- Various US federal, US state, other national and multinational initiatives in the 2000s (including the August 9, 2001 White House policy restricting funding for hESC research to cell lines derived before that date) that have, in some jurisdictions, prohibited government funding of research with cell lines derived from hESCs and, in other cases, prohibited that research regardless of the source of funding.

The second set, in chronological order, comprises:

- The 1979 decision of the NIH Ethics Advisory Board that in vitro fertilization is worthy of federally funded study [4];

- The NIH Revitalization Act of 1993, which sought to eliminate the regulations underpinning the September 1980 decision against funding in vitro fertilization research;

- Promulgation of the $2000 \mathrm{NIH}$ Guidelines for federal funding of research using hESC cell lines derived with nonfederal funding;

- State and philanthropically funded research in several places around the world during the 2000s;

- Adoption of, and initial operation under, the 2009 NIH Guidelines for hESC and induced pluripotent stem cell research in response to the March 2009 US presidential executive order directing the NIH to "support and conduct responsible, scientifically worthy human stem cell research, including human embryonic stem cell research, to the extent permitted by law" [105].

As a target, the 2009 NIH Guidelines illustrate thefourtharrowin theadvocate's quiver: litigation. For example, after being authorized by voters in California, the California Institute of Regenerative Medicine (CIRM) initially encountered 2 years of litigation challenging CIRM's authority to issue bonds for stem cell research. In Germany, a lawsuit originally filed in 2004, and pending before the European Court of Justice as this article went to press, challenges the validity of a German patent issued in 1999 that claims the invention of a cell-based treatment for neuronal disease with neurons derived from hESCs [106]. In addition, in the USA, in the case of Sherley et al. versus Sebelius et al., filed in August 2009 in federal District Court in Washington, DC, the two plaintiffs, adult stem cell researchers, argued that NIH funding of research with cell lines derived from hESCs (whatever the source of funding for such derivation) violates the Dickey-Wicker Amendment and that the procedures used by the NIH for adopting the 2009 Guidelines violated the Administrative Procedure Act (the law governing adoption of regulations by agencies within the US government's executive branch) [107]. In July 2011, after almost 2 years of wrangling on standing and preliminary injunction issues in both the District Court and the Circuit Court of Appeals for the District of Columbia, the District Court ruled in favor of the government's motion for summary judgment, thereby allowing the NIH to proceed funding hESC research under its 2009 Guidelines. As this article went to press, an appeal by plaintiffs was possible but had not been filed.

The aforementioned legislation/ regulation/litigation dialectic suggests that stem cell research policy development, the fifth element of advocacy, has not matured to a steady state at the US federal level. While some 
stem cell research policy has borne fruit in some states (most notably, the states comprising the Interstate Alliance for Stem Cell Research [108]: California, Connecticut, Illinois, Maryland, Massachusetts, New Jersey, New York, Ohio, Rhode Island and Wisconsin) and by not-for-profit organizations such as the Harvard Stem Cell Institute and the New York Stem Cell Foundation, the historic absence of full-scale US federal involvement in hESC research may have limited not only hESC research itself, but also the stem cell field as a whole. We note here that the collaborations among stem cell researchers and clinicians around the world, mediated in significant part through the efforts of CIRM, has offered a model for broad geographic collaboration among stem cell advocates [109], but we nonetheless believe in the necessity for the NIH to take a sustained and leading role.

The globally oriented collaborative approach that has evolved for stem cell science should also be pursued for stem cell advocacy. The Stem Cell Action Coalition, initiated by Genetics Policy Institute in November 2010, exemplifies this pursuit. The Coalition seeks to serve "as an engine uniting the procures community" by maintaining a continually curated website, hosting periodic conference calls among the advocacy groups comprising the Stem Cell Action community, and preparing and disseminating periodic newsletters [110]. The annual World Stem Cell Summit, produced and co-organized by the Genetics Policy Institute, provides another example of collaboration among stem cell advocates. The Summit "brings together scientists, patients, advocates, business people, investors, educators, ethicists, policy makers and government representatives from around the world" [111]. The Alliance for Regenerative Medicine offers a third example of the collaborative approach to advocacy. The Alliance for Regenerative Medicine focuses on "legislative, regulatory and reimbursement initiatives necessary to facilitate access to life-giving advances in regenerative medicine" [112]. Alliance for Regenerative Medicine's members include over 80 organizations, including companies, research organizations, investors, and patient advocacy groups.

Turning to education, we propose a simplified bench-to-public knowledge model consisting of three reservoirs of scientific and medical knowledge (FIgurE 1):

- Scientific experiments and clinical studies

- Scientific publications relating to those experiments, studies and their results

- Publications in the lay media relating to the first two reservoirs

As a proxy for the first reservoir, we use annual NIH research awards (a proxy for clinical studies would be the ClinicalTrials.gov database); for the second reservoir, the annual number of publications listed in the PubMed database maintained by the US National Library of Medicine (this second reservoir could be expanded to include online patent databases and disclosure documents mandated by securities laws); and for the third reservoir, an online database of news articles. We have applied this model to four fields within stem cell science and a control field: stem cells in general; hESCs; adult stem cells; induced pluripotent stem (iPS) cells; and, as the control, nanobased medical technology (TABLE 1 ). Presentation and analysis of the data from this exercise extends beyond this paper, but we offer some very general observations:

- iPS cells seem to be growing into a position of dominance at the experimental level, leading to a rapid increase in the annual number of iPSC scientific papers and related reports in the lay media;

- The number of research awards for hESCs and adult stem cells seem to exhibit a 2-year up/down cycle, with local peaks in 2003, 2005, 2007 and 2009;
- The number of reports regarding hESCs and adult stem cells in the lay media in the USA during 2008 through 2010 fell sharply from the peak level experienced in 2005;

- The number of reports in the lay media in the USA regarding 'stem cells, in general' has fallen from its peak in 2005, but may be experiencing an upswing driven by reports on iPSCs;

- Except for some volatility in the lay media in the early 1990s, experiments, scientific reports and lay reports for nano-based medical technology do not present as much volatility as do stem cell-based fields.

Optimizing the information flow from the laboratory to public media through innovative collaboration and education can play a key role in stem cell advocacy. Toward this vision we propose development of the Stem Cell Information Technology Platform - a linked database, semantic web, ontologically driven information system that uses the various dissemination tools within the Internet Cloud/Apps/Social Media. The Stem Cell Information Technology Platform ontology could serve as a map of the relationships among the components of information on stem cell science and its clinical translation into medicine. This ontology would enable all interested stakeholders to contribute to models of stem cell science and its clinical translation, and would, in turn, support progress in the other elements of stem cell advocacy discussed above. We propose the formation of a working group to focus on constructing this ontology.

The next 5-10 years of stem cell advocacy may turn, in significant part, on the ability to implement innovative, collaborative tools to educate all stakeholders about the benefits and costs of stem cell science and its translation into medicine. We envision two such tools here: a preliminary model of the 'benchto-public knowledge' process; and a 
Scientific experiments

- Proxy: number of new NIH research awards;

$\mathrm{SC}$ measured by right axis; others left axis

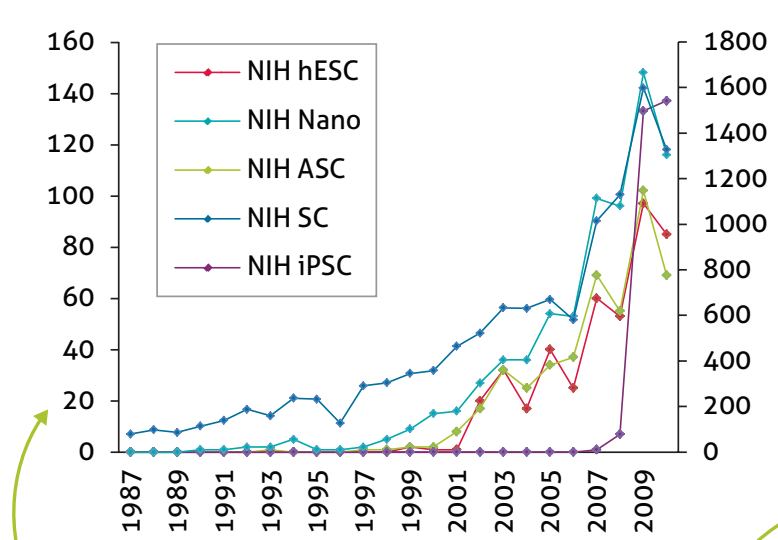

\section{Scientific reporting}

- Proxy: number of publications listed in PubMed [5]";

$\mathrm{SC}$ measured by right axis; others left axis

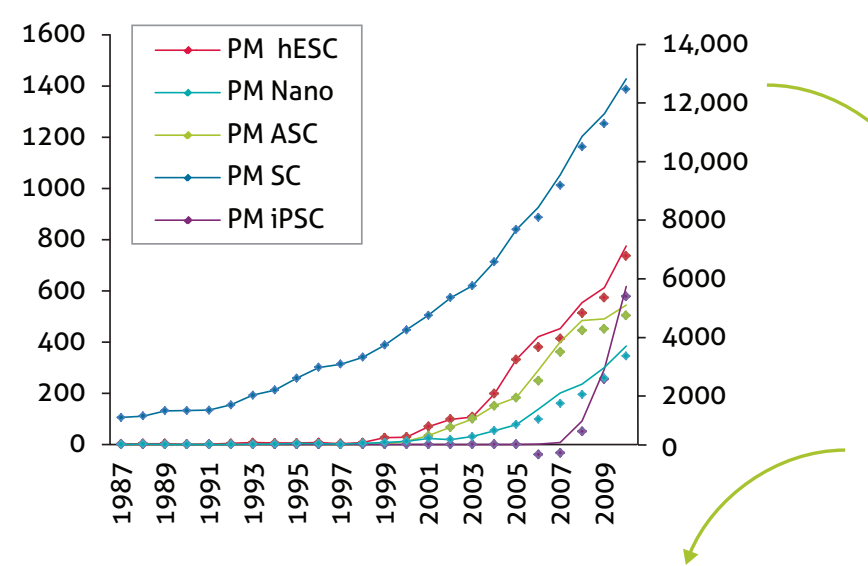

Lay reporting in the USA

- Measured by publications listed in WestLaw "ALLNEWS"

Library"; lay SC measured by right axis; others left axis

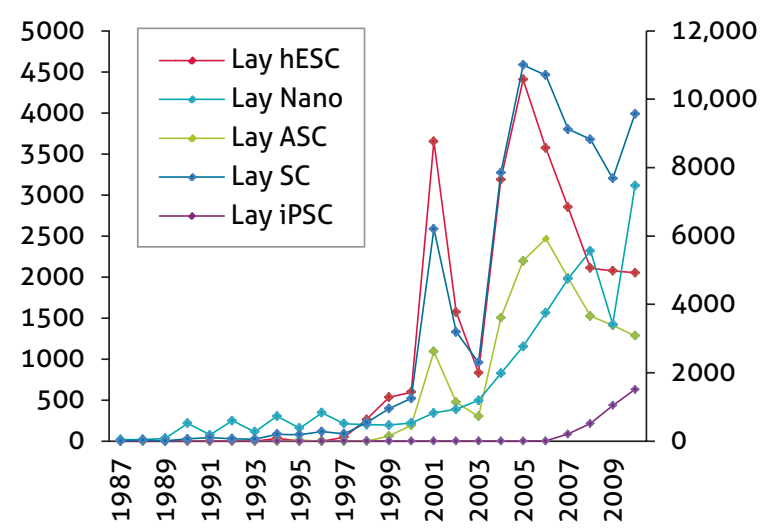

Scientific experiments-to-scientific reporting

- Ratio of scientific reports to

$\mathrm{NIH}$ awards

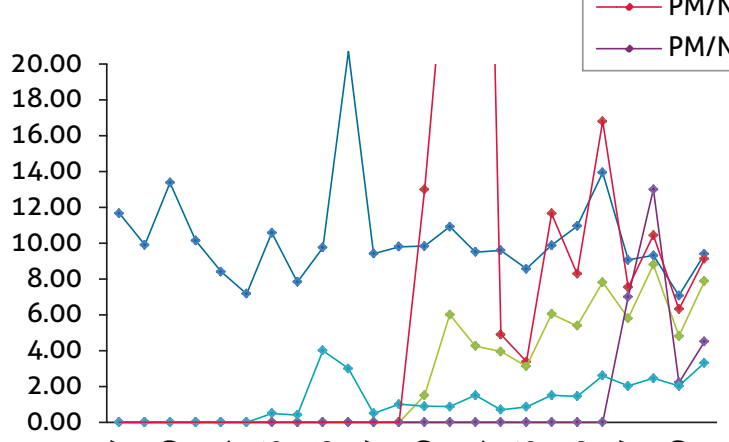

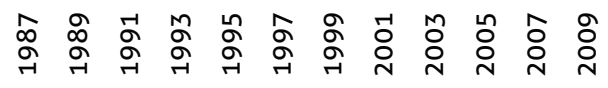

Lay reporting-to-scientific reporting

- Ratio of lay reports to scientific reports

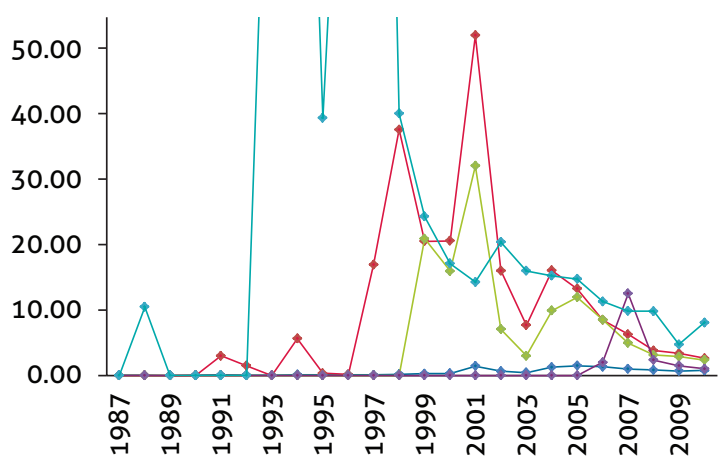


Figure 1 (Left). A proposed 'benchto-public knowledge' model. tThe first article that appears in the 89,645 articles in PubMed in response to the search string 'stem cell' is [5].

‡In a New York Times article published February 24, 1976, titled "Frontiers of Science, From Microcosm to Macrocosm," Walter Sullivan wrote

"[d]uring the next few years scientists may find an efficient way to derive fuel from water, using sunlight, or fathom the process whereby a single egg cell differentiates into the multifarious cells of a human being" [6].

ASC: Adult stem cell; hESC:

Human embryonic stem cell; iPSC: Induced pluripotent stem cell; Nano: Nanomedicine; PM: PubMed; SC: Stem cell. semantic web information platform. The conception of these two tools, each of which requires substantial further development, arises from the principle 'you only get what you can measure'. We believe this principle applies to all the elements of advocacy, and we urge its consideration by stem cell advocates.

Financial \& competing interests disclosure The law firm in which AL Jakimo is a partner represents numerous life science, pharmaceutical, medical device and healthcare companies. The authors have no other relevant affiliations or financial involvement with any organization or entity with a financial interest in or financial conflict with the subject matter or materials discussed in the manuscript apart from those disclosed.

No writing assistance was utilized in the production of this manuscript.

\begin{tabular}{|c|c|c|c|}
\hline & NIH RePORTER ${ }^{\dagger}$ & PubMed & $\begin{array}{l}\text { Thomson Reuters WestLaw - ALLNEWS } \\
\text { Library }{ }^{\ddagger}\end{array}$ \\
\hline SCs, generally & $\begin{array}{l}\text { Term search: 'stem cell' OR } \\
\text { 'stem cells' } \\
\text { Fiscal Year: YYYY } \\
\text { Chart Code: NIH SC }\end{array}$ & $\begin{array}{l}\text { Human AND ('stem cell' OR } \\
\text { 'stem cells') AND 'YYYY' } \\
\text { [Publication Date] } \\
\text { Chart Code: PM hESC }\end{array}$ & $\begin{array}{l}\text { Human \& ('stem cell' OR 'stem cells') \& } \\
\text { da(YYYY) } \\
\text { Chart Code: Lay SC }\end{array}$ \\
\hline hESCs & $\begin{array}{l}\text { Term search: 'human } \\
\text { embryonic stem cell' OR } \\
\text { 'human embryonic stem } \\
\text { cells' } \\
\text { Fiscal Year: YYYY } \\
\text { Chart Code: NIH hESC }\end{array}$ & $\begin{array}{l}\text { ('Human embryonic' OR } \\
\text { 'human embryo') AND ('stem } \\
\text { cell' OR 'stem cells') AND } \\
\text { 'YYYY' [Publication Date] } \\
\text { Chart Code: PM hESC }\end{array}$ & $\begin{array}{l}\text { ('Human embryonic' OR 'human embryo') } 8 \\
\text { ('stem cell' OR 'stem cells') \& da(YYYY) } \\
\text { Chart Code: Lay hESC }\end{array}$ \\
\hline ASCs & $\begin{array}{l}\text { Term search: 'adult stem } \\
\text { cell' OR 'adult stem cells' } \\
\text { Fiscal Year: YYYY } \\
\text { Chart: NIH ASC }\end{array}$ & $\begin{array}{l}\text { Human AND ('adult stem cell' } \\
\text { OR 'adult stem cells') AND } \\
\text { 'YYYY' [Publication Date] } \\
\text { Chart Code: PM ASC }\end{array}$ & $\begin{array}{l}\text { Human \& ('adult stem cell' OR 'adult stem } \\
\text { cells') \& da(YYYY) } \\
\text { Chart Code: Lay ASC }\end{array}$ \\
\hline iPSCs & $\begin{array}{l}\text { Term search: 'induced } \\
\text { pluripotent stem cell' OR } \\
\text { 'induced pluripotent stem } \\
\text { cells' } \\
\text { Fiscal Year: YYYY } \\
\text { Chart Code: NIH iPSC }\end{array}$ & $\begin{array}{l}\text { Human AND ('induced } \\
\text { pluripotent') AND ('stem cell' } \\
\text { OR 'stem cells') AND 'YYYY' } \\
\text { [Publication Date] } \\
\text { Chart Code: PM iPSC }\end{array}$ & $\begin{array}{l}\text { Human \& ('induced pluripotent') \& ('stem } \\
\text { cell' OR 'stem cells') \& da(YYYY) } \\
\text { Chart Code: Lay iPSC }\end{array}$ \\
\hline Nanotechnology & $\begin{array}{l}\text { Term search: nano } \\
\text { Fiscal Year: YYYY } \\
\text { Chart Code: NIH Nano }\end{array}$ & $\begin{array}{l}\text { Human AND nano AND (drug } \\
\text { OR medicine OR medical) } \\
\text { NOT NANO[Author] AND } \\
\text { '2010' [Publication Date] } \\
\text { Chart Code: PM Nano }\end{array}$ & $\begin{array}{l}\text { Human AND nano! AND (drug OR medicine } \\
\text { OR medical) \& da(YYYY) } \\
\text { Chart Code: Lay Nano }\end{array}$ \\
\hline
\end{tabular}


Key points

- Stem cell advocacy needs to engage in quantitative self-analysis to assess its progress and future.

- Eight measurable elements of advocacy are described: agitation, legislation, regulation, litigation, policy development, collaboration, education and innovation.

- For each of these eight elements, stem cell advocacy may get poor to just passing scores.

- Innovation in stem cell advocacy needs to be pursued.

- We describe a 'bench-to-public knowledge' model for measuring the accumulation and dissemination of knowledge regarding stem cell science and its translation into medicine.

- We suggest that a semantic web information system available within the Internet Cloud/Apps/Social Media may provide an innovative and collaborative platform for stem cell advocacy education.

- We propose formation of a working group with representatives from multiple stakeholders to construct a semantic web ontology for modeling knowledge of stem cell science and its clinical translation into medicine.

- These models could support the various elements of stem cell advocacy.

\section{Bibliography}

1 Levine AD. Policy uncertainty and the conduct of stem cell research. Cell Stem Cell 8(2), 132-135 (2011)

2 Bartholet J. Inside the meat lab. Sci. Am. 304(6), 64-69 (2011).

3 Norman C. IVF research moratorium to end? Science 241(4864), 405-406 (1988).

4 Culliton BJ. Ethics advisory board confronts conception in the test tube. Science 202(4364), 198-199 (1978).

5 Sabin FR, Doan CA, Forkner CE. The production of osteogenic sarcomata and the effects on lymph nodes and bone marrow of intravenous injections of radium chloride and mesothorium in rabbits. J. Exp. Med. 56(2), 267-289 (1932).

6 Sullivan W. Frontiers of Science, From Microcosm to Macrocosm. The New York Times, NY, USA, 24 February 1976.

\section{- Websites}

101 Kennedy RF Jr. Interview with Tavis Smiley www.pbs.org/wnet/tavissmiley/interviews/ environmental-advocate-robert-f-kennedy-jr
102 National Association for the Advancement of Colored People (NAACP) www.communityinvestmentnetwork.org/ nc/single-news-item-states/article/nationalassociation-for-the-advancement-of-coloredpeople-naacp/?tx_ttnews $\% 5$ BbackPid $\% 5 \mathrm{D}$ $=1242 \& \mathrm{cHash}=093 \mathrm{e} 2652 \mathrm{fb} \& \mathrm{xype}=98$

103 NIH. Stem cell science information glossary

http://stemcells.nih.gov/StemCells/

Templates/StemCellContentPage.aspx?NR MODE $=$ Published \&NRNODEGUID $=\%$ 7b3C35BAB6-0FE6-4C4E-95F2-2CB61 B58D96D\%7d\&NRORIGINALURL=\% 2finfo\%2fglossary\%2easp \&NRCACHEH INT=NoModifyGuest\#stemcells

104 Thomas ED. Bone marrow transplantation - past, present and future. Nobel lecture, 8 December 1990 http://nobelprize.org/nobel_prizes/ medicine/laureates/1990/thomas-lecture.pdf

105 President Barack Obama. Removing barriers to responsible scientific research involving human stem cells. Executive order, 9 March 2009 www.whitehouse.gov/the_press_office/ Removing-Barriers-to-ResponsibleScientific-Research-Involving-HumanStem-Cells

106 Noonan KE. European Court of Justice
Considers Embryonic Stem Cell Ban. iCELL News, 12 May 2011 http://investorstemcell.com/featured/ european-court-of-justice-considersembryonic-stem-cell-ban

107 Sherley et al. v . Sebelius et al., Civ. No. 1:09-cv-1575 (RCL), (D.C. 2011) http://news.sciencemag.org/ scienceinsider $/ 27 \% 20 \mathrm{July} \% 20 \mathrm{opinion} . \mathrm{pdf}$

108 The Interstate Alliance on Stem Cell Research www.iascr.org

109 California Institute of Regenerative Medicine. Collaborative Funding www.cirm.ca.gov/Collaborative_funding

110 Stem Cell Action Coalition www.stemcellaction.org/content/about-us

111 World Stem Cell Summit www.worldstemcellsummit.com/aboutsummit

112 Alliance for Regenerative Medicine www.alliancerm.org

113 RePORTER

http://projectreporter.nih.gov/reporter.cfm 